\title{
A STUDY ON THE FOOD PROCESSING INDUSTRY AND ITS QUALITY CONSCIOUS EFFECT
}

\author{
AASHISH. C. $I^{1}$ \& DIVYA. M. $\mathrm{S}^{2}$ \\ ${ }^{1}$ Professor Department of Management \& Commerce, Amrita School of Arts and Sciences, Mysuru, India \\ ${ }^{2}$ Research Scholar, Amrita School of Arts and Sciences, Mysuru, India
}

\begin{abstract}
Industrial Youngsters must be conscious about diet and physical activity, because second level employees will be in the process of planning. Therefore, they are conscious of the diet food. The blue collar people are conscious about their physical activity that are connected to shop floor, they have to be physically fit to handle the raw material before the complete assembly of the finished goods that take place. The main aim of this research paper is to understand the industrial youngsters' behavior towards diet food and relationships between income of industrial employees and diet food. Data was collected by using a structured questionnaire, 100 respondents were participated in the survey and data were collected in different location in Mysore suburban. These studies provide valuable insight regarding diet food by examining the income factor and consciousness towards diet food. The result indicates that industrial youngsters are conscious towards diet food and there is a relation between income and diet food. It is suggested to understand the needs, wants and attitude towards diet food and use them as marketing strategy to increase the sale and encourage people in following healthy diet.
\end{abstract}

KEYWORDS: Industrial Youngsters, Diet Food \& Income of Employees

Received: Jan 12, 2018; Accepted: Feb 02, 2018; Published: Mar 24, 2018; Paper Id.: IJMPERDAPR2018134

\section{INTRODUCTION}

Healthy eating helps in leading healthy life style. It contributes to overall growth and development of health including healthy skin, bones and energy level. Modern India is at nutriment and dietary crossroad, while historical India has problem of under nutrition and now have problem of overweight and obesity. Good nutrition is very important in enhancing health. Healthy life style combines with diet and physical activity, it helps to reduce different kind of diseases and maintain a healthy weight, being one of the prudent factors for today's Industrial employees.

\section{RESEARCH OBJECTIVES}

- $\quad$ To understand the relationship between income of industrial employees and diet food.

- To analysis the consciousness health towards diet food among industrial youngsters.

\section{METHODOLOGY}

This paper is based on primary and secondary data. Primary Data were collected using structured questionnaire in order to assess industrial youngster's response to diet food, 100 respondents were participated in the survey and data were collected in different locations in Mysore sub urban. Overall, the sample was reasonable 
representative of Mysore population. Secondary data were collected by referring different journals and websites

\section{Content}

A healthy diet means choosing best among many alternative foods, quality and quantity that matters. "Eating practices and behaviors towards them are consistent with improving our health”. Physical activity and the balanced diet is the foundation of health. Healthy diet, eating helps to maintain body's function and diet promotes have proper body weight assist in preventing disease. Unhealthy diet contains low intake of fruits, milk product, vegetables and high intake of food which contains high fats, sugar and calories. Consumption of unhealthy food invites many diseases like, heart problems, diabetes, breast, colon, endometrial cancer it also makes the person inactive. There were 9.8 million men and 20 million women in the obese category in 2014 in India. The country has seen a significant rise in obesity, ranking $5^{\text {th }}$ for men and $3^{\text {rd }}$ for women in 2014. Previously it was in $19^{\text {th }}$ position in the year 1975 . Obesity in India has reached epidemic proportion in $21^{\text {st }}$ century, with morbid obesity affecting $5 \%$ of the country's population. $14 \%$ male and $17.3 \%$ females are in the obese category in Karnataka and $12 \%$ male, $16 \%$ female are in the obese category in India.

Food habits have been changing among the people; they are making unhealthy food choices due to many reasons i.e. work pressure, unaware of diet food and healthy food, attraction towards junk food, less time etc. so it is necessary to have awareness about diet food, particular to the Industry. It is important that the people who work with the machineries, need to be conscious about the food they consume, thereby maintaining the balance diet which is an important factor in the shop floor. This paper focuses on 2 important factors, i.e. Industrial youngster's behavior toward diet food and factors that effects on the purchasing of diet food. There are many factors which effect on the purchasing of diet food, i.e. age, sex, availability, education, consciousness, income, etc. but this paper is focused on income of employee's factors.

Industrial Youngsters are those people whose age is between 15 to 25 and working in industrial units. Youngsters can be defining them as the period between childhood and adult age. It is a life period where the person is neither child nor adult.

Healthy Diet means those foods which help in maintaining a healthy weight. But many peoples' opinions that diet means food which containing low calories and helps in weight loss, not promote weight gain. It includes consumption of more fruits, vegetables and milk product.

"A healthy diet provides the body with essential nutrition: fluid, adequate essential amino acids from protein, essential fatty acids, vitamins, minerals, anti-oxidants, fibre and adequate calories". In simple, it can be defined as "eat less, move more, eat lots of fruits and vegetables, go easy on junk foods"

\section{LITERATURE REVIEW}

\section{“Determinates of Healthy Eating in Children and Youth”. 'Jennifer P. taylor', 'Susan evers' and 'Mary Mckenna'}

Healthy eating is the eating habit which helps in improving health. Media especially television has great impacts or influence on eating habit. Primary data were collected to determine the eating habits. They found that age, sex, nutritional attitudes, education, economic status, availability are the determinants of healthy eating.

\section{“Consumer Behaviour and Purchase Intention for Organic Food”. 'Fustin Paul' and 'JyothiRana'}

Objective of this paper is to know the intentions and buying behavior of organic food and the factors influencing towards organic food. Face to face interview was conducted using structured questionnaire. The result indicates that 
education, availability factors positively influence consumer activity towards organic food. This study also suggests the retailers have to bring marketing strategies and programs to influence customers.

"Effects of Junk Food and Beverages on Adolescents Health"- review article. 'GeetaArya' and 'Sunita Mishra'

This paper gives clear picture about junk food. It contains more fats and calories and can lead to a variety of health problems. School canteen plays a major role where they offer junk food to students and this result in increased weight of youth. Consumption of junk food may lead to diabetes and many diseases. According to WHO, in India more than $3 \%$ of the population is in the obese category.

"Functional Food Knowledge and Perception among Young Consumer in Malaysia", World Academy of science, engineering and technology

The objective of this paper was to find socio- economic factors that influenced on functional food and to know the attitude, influence and awareness of functional food. A questionnaire was used to find the results. They found that income, age, food safety, working environment influences on Malaysian consumer towards healthy food.

"New Generation Youth Lifestyle and Food Consumption Pattern”. 'Asha Joshi'

This paper suggests to take the responsibility in raising and becoming healthy human beings. More than $20 \%$ of world's population consist of youth so it is necessary to have awareness about healthy food consumption. They also suggest that it is necessary to provide education which is related to health, healthy life cycle.

Understanding Eating Behaviour of New Dehli's Youth.'Milissa Harrell, 'Jose medina, blanche Greene-Cramer, Shreela V. Sharma, Monika Arora

Particularly Indian urban youth affected by dietary dichotomy. Results show that $10 \%$ to $30 \%$ of children and adults are overweight. There are many factors like lack of physical activity, environment, cultural, genetic may put youths under obese category. This paper tries to understand the eating pattern, attitude and knowledge towards unhealthy and healthy eating.

\section{Factors Influencing Consumer Behaviour, 'Pinki Rani'}

Consumer buying pattern depends on many factors. Buying behavior is the decision making process where decisions depend on social class, family, membership group, personality, culture and psychological factors. When factors which influence on buying behavior are identified it helps in developing marketing strategies and meet the needs of its consumer with rising sales.

Low-Income Consumers' Attitude and Behavior towards Access, Availability and Motivation to Eat Fruits and Vegetables, LA Dibsdall, $n$ lambert, Rf bobbin and LjFrewer

This paper says that employment, age, smoking, gender and marital status influence to buy fruits and vegetables. This paper suggests to focus on motivating to buy and eat fruits and vegetables. "National and international bodies have focused increasing effort in recent years on defining and promoting healthy diets".

An exploration of the Relationship between Income and Eating bBehaviour, Susan e. Jing, and James k. Binkley`

This paper examines the relationship between eating behavior and income. Some have argued that their programs 
designed to eliminate food insecurity are also structured to encourage overconsumption. This study found a positive relation between the location of fast food and low income neighborhoods.

Unhealthy Diet and Physical Inactivity. WHO 2009

Unhealthy diet and physical inactivity are major reasons for type 2 diabetes and certain cancer. The report says that 2.7 million deaths are accrued due to low consumption of fruits and vegetables and 1.9 million deaths are attributed to physical inactivity.

\section{What is Sustainable Health Diet?, 'Tara Garnett' food climate research network April 2014}

The food system is unsustainable today. "The task, therefore, is to shrink our consumption pattern to fit the safe operating space available for humanity". We should fairly reduce the consumption of animal product.

Impact of Food Advertisement in Social Media among Local University Student in Malaysia, 'Ai ling, tan and PohTheng,Loo

The main aim of this paper is to know the impact of social media among local university student. The study found that social media, providing information to university student and they are useful and valuable for them. According to Mahadi report, $45.5 \%$ of the total Malaysia population using Facebook among which highest user are people who is between 18 to 24 . So, food industries may use social media for promoting their commodities.

\section{Food Poverty. What does the Evidence tell us?, Nick Smith, Angela Raffle, Steve Marriott, Nick Smith}

"Food poverty is the inability to offer for a healthy diet including quality and quantity of food. It is found that low income group can't offer for fruits and vegetables. It focuses on financial, physical and social factors relating to food.

\section{Healthy Food for Life}

Food pyramid guide to everyday food choices for adults, teenagers and children's aged five and over. It suggested that everyone should take plan before having meal, prepare with fresh ingredients, use healthy cooking methods, s and take time to enjoy meals.

The Role of Health Consciousness, Food Safety Concern and Ethical Identity on Attitude and Intentions toward Organic Food

Research indicates that food safety as the most important predictor of attitude while health consciousness appears to be the least important motive in contrast to findings from some previous research and food safety concern and ethical self-identity as the most important predictors of attitudes towards organic produce.

\section{Analysis and Interpretation}

Chi- square test is calculated to analyze the consciousness among industrious youngsters towards diet food. An interest that makes industrial youngsters to follow a healthy diet. 
Table 1

\begin{tabular}{|c|c|}
\hline Sl. No & Values \\
\hline 1 & 6 \\
\hline 2 & 50 \\
\hline 3 & 22 \\
\hline 4 & 22 \\
\hline
\end{tabular}

$\mathbf{H}_{\mathbf{0}}: 70 \%$ of industrial youngsters are not conscious towards diet food

$\mathbf{H}_{1 \mathbf{s}}: 70 \%$ of industrial youngsters are conscious towards diet food.

Expected frequency $=$ total frequency/total number

$100 / 4=25$

Chi-square $=$ sigma $(\mathrm{Oi}-\mathrm{Ei}) / \mathrm{Ei}$

$=\left[\left(6-25^{2} / 25\right)+\left(50-25^{2} / 25\right)+\left(22-25^{2} / 25\right)+\left(22-25^{2} / 25\right)\right]$

$=39.56$

Degree of freedom $=(n-1)$

$(4-1)=3$

Alpha value $=0.05$

Table value $=7.81$

Interpretation: According to the hypothesis, taken at alpha value being 0.05 or $95 \%$ confidential level with degrees of freedom being 3. Null hypothesis which is so stated, is rejected. Therefore, an alternative hypothesis which stated that "70\% of industrial youngsters are conscious towards diet food" is accepted.

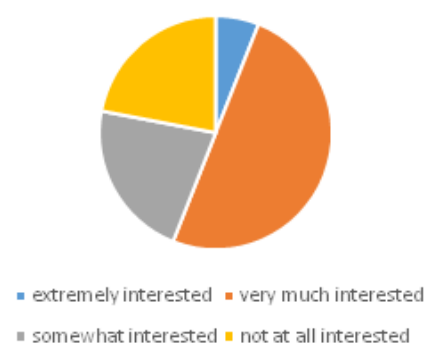

Figure 1

Inference: extremely interested $6 / 100=0.06$

Very much interested 50/100=0.5

Somewhat interested $22 / 100=0.22$

Not at all interested $22 / 100=0.22$

In the question 4, options were taken namely, extremely interested, very much interested, somewhat interested and not at all interested. Out of which $50 \%$ of sample size are likely to be interested in following a healthy diet. 


\section{Correlation is Calculated to Analysis the Relation Between Income and Diet Food}

$\mathrm{H}_{0}$ : There is no relation between income of employees and diet food.

$\mathrm{H}_{1}$ : There is a relation between income of employees and diet food

$\mathrm{X}=$ income

$\mathrm{Y}=$ diet food

Table 2

\begin{tabular}{|c|c|c|c|c|}
\hline $\mathrm{x}$ & $\mathrm{y}$ & $\mathrm{X}^{2}$ & $\mathrm{Y}^{2}$ & $\mathrm{Xy}$ \\
\hline 36 & 28 & 1296 & 784 & 1008 \\
\hline 26 & 35 & 676 & 1225 & 910 \\
\hline 18 & 20 & 324 & 400 & 360 \\
\hline 20 & 17 & 400 & 289 & 340 \\
\hline Total=100 & Total=100 & Total=2696 & Total=2698 & Total=2618 \\
\hline
\end{tabular}

$(\mathrm{r})=\left[\mathrm{N} \Sigma \mathrm{XY}-(\Sigma \mathrm{X})(\Sigma \mathrm{Y}) / \operatorname{Sqrt}\left(\left[\mathrm{N} \Sigma \mathrm{X}^{2}-(\Sigma \mathrm{X})^{2}\right]\left[\mathrm{N} \Sigma \mathrm{Y}^{2}-(\Sigma \mathrm{Y})^{2}\right]\right)\right]$

$4 * 2618-(100)(100) / \operatorname{sqrt}\left(\left[4 * 2696-(100)^{2}\right]\left[4 * 2698-(100)^{2}\right]\right)$

472/sqrt784* sqrt792

$472 / 28 * 28.14$

Correlation $=0.599$

Interpretation: since the value is 0.599 which is positive therefore it indicates a positive relation between income of employees and diet food.

Table 3

\begin{tabular}{|l|c|}
\hline \multicolumn{1}{|c|}{ options } & percentage \\
\hline A:low calorie food & 14 \\
\hline B:low fat & 62 \\
\hline C:low sugar & 14 \\
\hline D:other & 10 \\
\hline
\end{tabular}

\section{What Does Diet food means to You?}

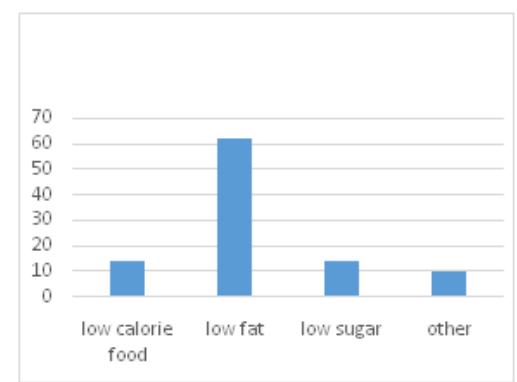

Figure 2

Inference: low calories $14 / 100=0.14$

Low fat $62 / 100=0.62$ 
Low sugar $14 / 100=0.14$

Other $10 / 100=0.1$

In the question, 4 options were taken namely low calories, low fat, low sugar and other. $62 \%$ of sample size responded that it means low fat.

\section{Industrial Youngsters Responsible Towards Planning Meal}

\section{Table 4}

\begin{tabular}{|l|c|}
\hline \multicolumn{1}{|c|}{ options } & percentage \\
\hline A: little & 10 \\
\hline B:about half & 26 \\
\hline C:most & 40 \\
\hline D:none & 24 \\
\hline
\end{tabular}

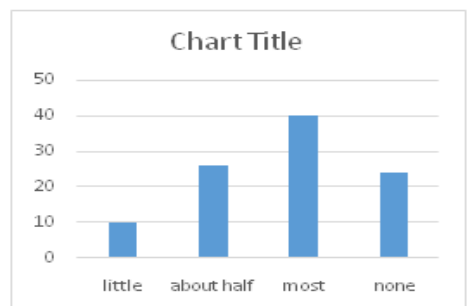

Figure 3

Inference: little 10/100=0.1

About half $26 / 100=0.26$

Most 40/100=0.4

None $24 / 100=0.24$

In the question, 4 options were taken namely little, about half, most and none. $40 \%$ of sample size responded that they are most responsible towards planning meals.

\section{Rankings According to Preference for Reducing Weight}

Table 5

\begin{tabular}{|l|c|}
\hline \multicolumn{1}{|c|}{ options } & rank \\
\hline Yoga & 1 \\
\hline Exercise/gym & 3 \\
\hline diet & 2 \\
\hline surgery & 4 \\
\hline
\end{tabular}

Inference: people prefer yoga to reduce weight than diet, exercise and surgery.

\section{Preference toward Diet Food if Income of Employees is Raised}

\section{Table 6}

\begin{tabular}{|l|c|}
\hline \multicolumn{1}{|c|}{ options } & Percentage \\
\hline A:yes & 56 \\
\hline B:no & 44 \\
\hline
\end{tabular}




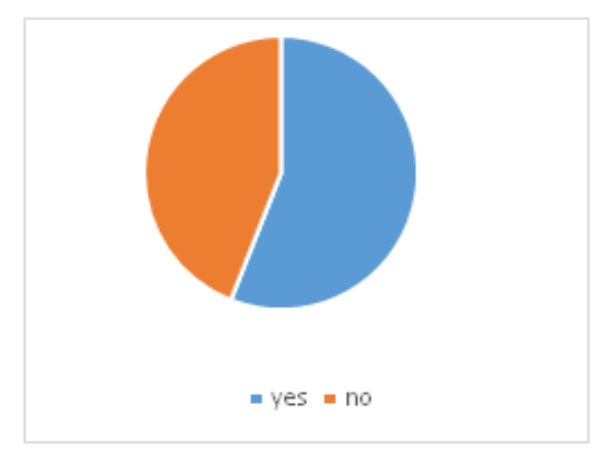

Figure 4

Inference: $56 \%$ of people say that they prefer diet food if their income is raised and $44 \%$ people not prefer diet food if their income is raise

\section{Preference among Industrial Youngsters to Have Rice in a Day?}

Table 7

\begin{tabular}{|l|c|}
\hline \multicolumn{1}{|c|}{ options } & percentage \\
\hline A:3 times & 10 \\
\hline B:2 times & 70 \\
\hline C:1 times & 20 \\
\hline D:never & 0 \\
\hline
\end{tabular}

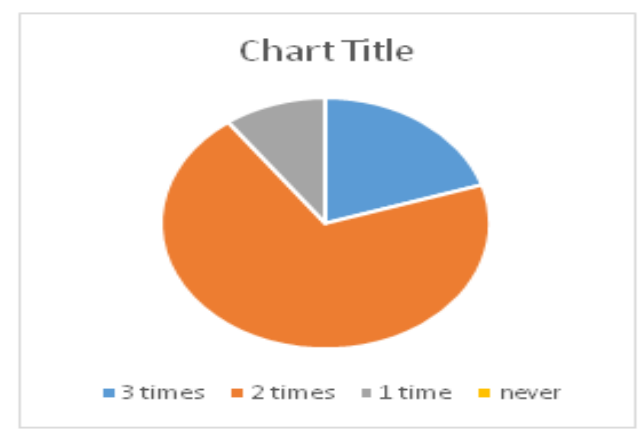

Figure 5

Inference: 3 times consumption of rice per day 10/100=0.1

2 times consumption of rice per day $70 / 100=0.7$

1 time consumption of rice per day $20 / 100=0.2$

In the question, 4 options were taken namely 3 times, 2 times, 1 time and never. $79 \%$ of sample size prefer to have 2 times rice per day.

\section{CONCLUSIONS}

The result shows that majority of Industrial youngsters have a positive perception towards diet food. There were 100 respondents out of which more than $70 \%$ of respondents follow a healthy diet. Most of the respondents believe that diet food is that which contain low fat. Diet food got rank 2 for reducing weight and industrial youngsters feel that practicing yoga is better than diet, gym and surgery for reducing weight. Result found that $60 \%$ of respondents are consuming vegetables, fruits and dairy product almost everyday, which is a good indicator of healthy food habit. However, 
majority of Industrial youngsters agreed to prefer diet food if their income is raised and people who already purchased diet food wants to increase the quality and quantity of diet food if their income is raised. In addition, being healthy and diet conscious is the important factor for developing healthy eating habit.

\section{REFERENCES}

1. Drewnowski A. Taste preferences and food intake. Annu Rev Nutr1997; 17:237-53.

2. Hill JO, Peters JC. Environmental contributions to the obesity epidemic.Science 1998; 280:1371-74.

3. Morten Sune Jonas, Suzanne C. Beckmann. Functional food: Consumer Perception in Denmark and England, Oct 1998, 1-33.

4. leon g. schiffman and joseph wisenbit "consumer behaviour"

5. Wang Y, Chen HJ, Shaikh S, Mathur P. Is obesity becoming a public health problem in India? examine the shift from under-to overnutrition problems over time. Obes Rev. 2009; 10(4):456-474.

6. World academy of science, engineering and technology, Functional food knowledge and perception among young consumer in Malaysia.2012; vol:6.

7. Nagpur college of pharmacy, Nutraceutical- definition and introduction, april 15, 2003.

8. Juliana Cáceres-Medina, Carolina Bassol-Cámara, Katherine Aguilar-Várguez,Carlos Blanco-Centurión, Jaime Zaldivar-Rae \& Eric Murillo-Rodríguez, Endogenous Levels of Adenosine in Obese Patients Before and After Hypocaloric Diet Treatment, International Journal of Medicine and Pharmaceutical Sciences (IJMPS), Volume 5, Issue 3, May - June 2015, pp. 1-8

9. Tara Garnett, What is a sustainable health diet?- a discussion paper, april 2014.

10. Kalra S, Unnikrishnan AG. Obesity in India: the weight of the nation. J Med NutrNutraceuticals. 2012;1(1):37-41

11. World Health Organization. Unhealthy diets and physical inactivity.World Health Organization website.

http://www.who.int/nmh/publications/fact_sheet_diet_en.pdf. Published June 2009. Accessed October 7, 2015

11 Swaminathan S, Thomas T. Perceptions of healthy eating: a qualitative study of school-going children in South India. Health Educ J. 2009;68(2):94-110

12 Swaminathan S, Thomas T, Kurpad AV, Vaz M. Dietary patterns in urban school children in South India. Indian Pediatr. 2007; 44(8):593-596.

13 Vijayapushpam T, Menon KK, Rao DR, Antony GM. A qualitative assessment of nutrition knowledge levels and dietary intake of schoolchildren in Hyderabad.Public Health Nutr. 2003; 6(7):683-688.

14 Stigler MH, Arora M, Dhavan P, et al. Measuring obesity among school-aged youth in India: a comparison of three growth references. Indian Pediatr. 2011;48(2):105-110.

15 Timlin MT, Pereira MA, Story M, Neumark-Sztainer D. Breakfast eating and weight change in a 5-year prospective analysis of adolescents: Project EAT (Eating Among Teens). Pediatrics. 2008; 121(3):e638-e645.

16 Shaw A, Mathur P, Mehrotra NN. A study of consumers' attitude toward processed foods. Indian Food Packer. 1993; 47:2941. 
